\title{
Kejadian malaria dan status gizi balita di Kabupaten Manokwari Provinsi Papua Barat
}

The incidence of malaria and nutrition status of children in Distric Manokwari of Province West Papua

Therresse Nofianti

\begin{abstract}
Background: The prevalences of severe acute malnutrition, moderate acute malnutrition and low birth weight (LBW) in West Papua Province is higher than the national prevalence. Malaria disease especially in infant, is also of concern in this province. Manokwari District is regarded as malaria endemic area due to the high morbidity rate in the entire district. Objective: To determine the incidence of malaria, nutritional status of children and to analyze the relationship between two of them. Method: The methodology that used in this research is cross-sectional design conducted in four health centers in Manokwari with a sample of 100 children aged two to five years. The data were analized using Chi-Square analysis and logistic regression analysis. Results: The incidence rate of malaria in Manokwari district is high. This is because the number of infant that was infected highly and lowly by malaria do not vary much. Results shows that $42 \%$ children suffering from severe malaria, particularly tropical malaria type, with a frequency of more than two times in six months so that it had direct effect on appetite and weight. Average nutritional status based on weight/height and height/age is normal while according to weight/age is not normal. Infants with severe and moderate acute malnutrition are not found in this study. Conclusion: The incidence rate of malaria in children under five in the district of Manokwari is high, the nutritional status of children under five in the past are in the normal category and at the time of the study were not normal, this is due at the time of the study many infants experience pain and therefore contributes to the appetite that directly affect body weight of infants. Furthermore, it is known that there is a relationship between the incidence of malaria by the nutritional status of children in the district of Manokwari.
\end{abstract}

KEY WORDS: malaria, nutritional status, children, malnutrition, Manokwari, West Papua

\begin{abstract}
ABSTRAK
Latar belakang: Prevalensi gizi buruk, gizi kurang, dan berat bayi lahir rendah (BBLR) di Provinsi Papua Barat berada di atas prevalensi nasional. Malaria menjadi salah satu penyakit yang diwaspadai di provinsi ini terutama jika menyerang balita. Besarnya angka kesakitan yang tinggi bahkan hampir di seluruh daerah Kabupaten Manokwari sehingga termasuk dalam kategori endemis tinggi. Tujuan: Mengetahui tingkat kejadian malaria, status gizi balita serta menganalisis hubungan antara keduanya. Metode: Desain cross sectional yang dilakukan di empat puskesmas di Kabupaten Manokwari dengan sampel 100 anak berumur dua sampai lima tahun. Data diolah menggunakan analisis Chi-Square dan analisis regresi logistik. Hasil: Tingkat kejadian malaria di Kabupaten Manokwari tinggi. Tingginya kejadian malaria tersebut disebabkan jumlah balita yang sakit malaria baik berat dan ringan tidak berbeda jauh. Diketahui bahwa $42 \%$ balita menderita malaria berat yaitu malaria jenis tropika dengan frekuensi lebih dari dua kali dalam enam bulan sehingga secara langsung berpengaruh pada nafsu makan dan berat badan. Rerata status gizi balita berdasarkan BB/TB dan TB/U adalah normal sedangkan menurut BB/U tidak normal. Sementara itu, balita dengan status gizi buruk dan gizi lebih tidak ditemukan dalam penelitian ini. Simpulan: Tingkat kejadian malaria pada balita di Kabupaten Manokwari tergolong tinggi, status gizi balita pada masa lampau berada pada kategori normal dan pada saat penelitian berada dalam keadaan tidak normal. Hal ini disebabkan pada saat penelitian banyak balita mengalami sakit sehingga berpengaruh terhadap nafsu makan yang secara langsung berpengaruh terhadap berat badan balita. Terdapat hubungan antara kejadian malaria dengan status gizi balita di Kabupaten Manokwari.
\end{abstract}

KATA KUNCI: malaria, status gizi, balita, gizi kurang, Manokwari, Papua Barat

\section{PENDAHULUAN}

Masa balita merupakan usia penting dalam pertumbuhan dan perkembangan fisik anak karena pada usia ini anak masih sangat rawan terhadap berbagai gangguan kesehatan, baik jasmani maupun rohani.
Malaria menjadi salah satu penyakit yang harus selalu diwaspadai di Provinsi Papua Barat terutama jika menyerang balita. Malaria pada balita dikhawatirkan

Korespondensi: Jurusan Sosial Ekonomi Pertanian, Fakultas Pertanian, Universitas Negeri Papua, Jl. Cenderawasih No. C.83 Amban Manokwari, e-mail: ntherresse@yahoo.co.id 
dapat menyebabkan kecacatan permanen seperti lumpuh atau tuna ganda karena parasit malaria dapat menyerang otak dan menyebabkan berat badan lahir rendah (BBLR) pada bayi. Hasil penelitian yang dilakukan di Angola menyatakan bahwa kondisi masyarakat yang tinggal di daerah malaria umumnya mengarah ke status gizi buruk. Gizi buruk dan kekurangan gizi merupakan faktor risiko untuk terinfeksi malaria klinis (1).

Berdasarkan data Riset Kesehatan Dasar (Riskesdas), prevalensi nasional gizi buruk dan gizi kurang untuk kategori balita mengalami peningkatan dari tahun 2007 sampai 2010. Pada tahun 2010, prevalensi gizi buruk dan gizi kurang sebesar 6,5\% dan 8,2\%. Provinsi Papua Barat dan Papua memiliki prevalensi gizi buruk dan gizi kurang di atas prevalensi nasional yaitu sebesar 9,1\% dan 17,4\%. Pada tahun 2007, persentase BBLR tertinggi adalah Provinsi Papua Barat $(23,8 \%)$ sama halnya pada tahun $2010(23,8 \%)$ dan persentase BBLR sedikit lebih tinggi di pedesaan $(12,2 \%)$ dibandingkan di perkotaan $(10,8 \%)(2)$.

Berdasarkan penelitian di Kabupaten Purworejo diketahui bahwa infeksi malaria dapat mempengaruhi penurunan status gizi anak balita (3). Namun, penelitian lain juga menyebutkan bahwa kejadian malaria tidak berhubungan dengan status gizi pada balita di Kecamatan Kokap dan Samigaluh Kabupaten Kulon Progo Provinsi Daerah Istimewa Yogyakarta (DIY) (4). Sementara itu, disebutkan bahwa malaria dan kekurangan gizi juga menjadi penyebab morbiditas dan mortalitas yang tinggi di daerah pedesaan sub-Sahara Afrika. Di daerah tersebut ditemukan anak-anak kekurangan gizi kronis yang berisiko lebih tinggi mengalami malaria (5). Penelitian lain juga menyebutkan bahwa anak-anak di bawah lima tahun di Harcourt Nigeria memiliki tingkat parasit lebih tinggi $(36,36 \%)$ dan berisiko mengalami mordibitas dibandingkan dengan kelompok umur 5-8 tahun (21,27\%) sehingga perlu gizi yang cukup untuk menahan dampak negatif dari malaria (6).

Kabupaten Manokwari merupakan salah satu Kabupaten di Provinsi Papua Barat yang pada tahun 2010 sekitar $10 \%$ dari 2.270 balita yang ditimbang di posyandu dan puskesmas mengalami gizi buruk. Diketahui juga bahwa dari 22 Puskesmas, hanya 16 Puskesmas yang berjalan baik sedangkan posyandu hanya $80 \%$ dari 270 unit yang aktif. Selanjutnya, diketahui pada tahun 2011 jumlah balita yang terjangkit malaria diperkirakan sebanyak 17\% atau sekitar 918 balita. Jumlah penderita malaria yang meninggal terbanyak ada di Kabupaten Manokwari dan Fakfak (7). Besarnya masalah dan tingkat transmisi malaria di berbagai daerah sangat bervariasi sehingga untuk membedakannya dibuat pembagian berdasarkan besarnya angka Annual Parasite Incidence (API) yaitu angka kesakitan malaria (berdasarkan hasil pemeriksaan laboratorium) per 1000 penduduk dalam satu tahun per mil. Persebaran API di Kabupaten Manokwari menunjukkan bahwa seluruh daerah yang ada di kabupaten ini masuk dalam kategori endemis tinggi dengan angka API lebih dari 5\%o bahkan ada beberapa daerah-daerah dengan angka API lebih dari 134 \%o yaitu Manokwari Barat, Prafi, Anggi, Oransbari, dan Ransiki (7).

Di antara anak balita dengan gejala klinis malaria, hanya sekitar 4,4\% yang menerima pengobatan malaria, sementara balita yang menderita malaria umumnya hanya menerima obat untuk mengurangi demam (67,6\%) (2). Pemerintah Papua Barat telah berupaya untuk mengurangi kasus yang terjadi dan mewujudkan target bebas malaria di Papua Barat pada tahun 2030, diantaranya kerjasama dengan lembaga asing seperti Global Found maupun United Nations Children's Fund (UNICEF), pengadaan mikroskop, dan rapid test di seluruh puskesmas baik di perkotaan maupun pedalaman hingga anjuran pada masyarakat agar melakukan tes darah dan mengonsumsi obat yang benar. Namun, prevalensi dan penderita malaria masih tetap tinggi. Tujuan penelitian ini adalah untuk mengetahui status gizi balita dan menganalisis hubungan antara kejadian malaria dengan status gizi balita di Kabupaten Manokwari Provinsi Papua Barat.

\section{BAHAN DAN METODE}

Desain penelitian adalah cross sectional yang dilakukan di tiga kecamatan yang merupakan wilayah kerja Puskesmas Sanggeng, Wosi, Warmare, dan Prafi di Kabupaten Manokwari, Provinsi Papua Barat. Penelitian berlangsung dari bulan Mei sampai bulan Juli 2012. Pemilihan lokasi penelitian dilakukan secara purposife 
di tiga kecamatan dari 29 kecamatan berdasarkan jumlah penderita malaria paling banyak. Pemilihan dua puskesmas dari Kecamatan Manokwari Barat secara purposife dan masing-masing satu puskesmas dari Kecamatan Warmare dan Prafi sehingga diperoleh empat puskesmas. Populasi dalam penelitian ini adalah balita yang datang ke puskesmas untuk memeriksakan kesehatan. Sampel balita dengan kriteria inklusi pada saat penelitian yaitu anak berumur 2-5 tahun, berdomisili tetap di wilayah kerja puskesmas minimal 1 tahun atau lebih, dan ibu balita bersedia diwawancarai. Jumlah populasi balita di Kabupaten Manokwari tahun 2011 adalah 5.400 balita dan total balita di tiga kecamatan adalah 672 balita. Besar sampel minimum ditentukan dengan rumus Slovin, penentuan besar sampel untuk penelitian survei setelah diperoleh kriteria inklusi (8) sehingga diperoleh besar sampel minimum sebanyak 100 balita dan masing-masing puskesmas diambil 25 sampel dengan metode acak sederhana (simple random sampling).

Jenis data yang dikumpulkan terdiri dari data primer dan data sekunder. Data primer meliputi karakteristik keluarga (umur orangtua, pendidikan orangtua, pekerjaan, pendapatan, jumlah anggota keluarga), pengetahuan ibu tentang malaria, karakteristik balita (umur, jenis kelamin, berat lahir), dan kejadian malaria. Data tersebut dikumpulkan dengan teknik wawancara menggunakan kuesioner. Data status gizi balita diperoleh dengan cara pengukuran antropometri berdasarkan indeks berat badan per umur $(\mathrm{BB} / \mathrm{U})$, tinggi badan per umur $(\mathrm{TB} / \mathrm{U})$, dan berat badan per tinggi badan (BB/TB). Pengukuran $\mathrm{BB}$ menggunakan timbangan digital sedangkan untuk mengukur TB digunakan vertical measures (microtoise) untuk anak yang sudah bisa berdiri sendiri ( $\geq 2$ tahun) dengan ketelitian $0,1 \mathrm{~cm}$ yang dilakukan bersama suster dan perawat puskesmas setempat. Data sekunder terdiri dari data berat badan waktu lahir dari kartu menuju sehat (KMS), catatan puskesmas, dan data program penanggulangan malaria dari Dinas Kesehatan.

Data diolah menggunakan analisis univariat, bivariat, dan multivariat. Hubungan antara kejadian malaria dan status gizi diketahui dengan melakukan uji Chi-Square. Selanjutnya, untuk mengetahui faktor yang berpengaruh terhadap kejadian malaria dan status gizi balita digunakan analisis regresi logistik.

\section{HASIL}

\section{Karakteristik sosial ekonomi keluarga}

Berdasarkan Tabel 1 diketahui bahwa sebagian besar ibu balita berumur kurang dari 35 tahun. Rerata umur ibu adalah 28 tahun sedangkan rerata umur ayah 32 tahun. Diketahui juga bahwa sebagian besar (59\%) ibu memiliki jumlah anggota keluarga kurang dari 4 orang. Pendapatan merupakan salah satu faktor yang menentukan kuantitas dan kualitas makanan yang dikonsumsi sehingga berhubungan erat dengan status gizi. Keadaan ekonomi keluarga yang kurang mampu merupakan faktor yang kurang mendukung bagi pertumbuhan dan perkembangan anak balita. Hal ini disebabkan tingkat pendapatan keluarga sangat berpengaruh terhadap konsumsi pangan keluarga. Pada Tabel 1, diketahui bahwa 27\% ibu memiliki pendapatan keluarga dibawah upah minimum regional (UMR) Provinsi Papua Barat tahun 2012 yaitu kurang dari Rp 1.450.000. Rata-rata pendapatan adalah Rp 1.950 .000 dengan pendapatan tertinggi $\mathrm{Rp} 4.700 .000$ dan terendah Rp 300.000 .

Pendidikan sangat berkaitan dengan pekerjaan ibu karena semakin tinggi pendidikan maka akan semakin baik pekerjaan yang diperoleh. Hasil penelitian menunjukkan bahwa sebagian besar ibu balita berpendidikan rendah (SD dan SMP). Jika ditinjau dari pendidikan suami, $54 \%$ suami berpendidikan rendah dan $46 \%$ lainnya berpendidikan tinggi. Pekerjaan orang tua juga turut menentukan kecukupan gizi dalam sebuah keluarga. Semua ibu yang bekerja di rumah maupun di luar rumah, keduanya akan tetap meninggalkan anak-anaknya untuk sebagian besar waktu. Pekerjaan responden sebagai ibu rumah tangga diharapkan dapat lebih banyak memberi waktu dalam pengasuhan bayinya. Hal ini sejalan dengan penelitian yang dilakukan di Kabupaten Gianyar bahwa ibu yang bekerja di luar rumah merupakan salah satu penyebab atau risiko yang dapat mengakibatkan pola asuh ibu yang tidak baik pada anak (9). Meskipun pekerjaan dapat meningkatkan aksesibilitas rumah tangga terhadap pendapatan, tetapi mungkin juga memiliki efek negatif terhadap status gizi anak karena mengurangi waktu ibu untuk perawatan anak. Berdasarkan hasil penelitian ini diketahui bahwa sebagian besar ibu tidak bekerja sedangkan semua ayah memiliki pekerjaan. 
Tabel 1. Distribusi frekuensi berdasarkan kejadian malaria dan karakteristik sosial ekonomi keluarga

\begin{tabular}{|c|c|c|c|c|c|c|c|}
\hline \multirow{3}{*}{ Variabel } & \multicolumn{4}{|c|}{ Kejadian malaria } & \multirow{2}{*}{\multicolumn{2}{|c|}{ Total }} & \multirow{3}{*}{$\mathbf{p}$} \\
\hline & \multicolumn{2}{|c|}{ Rendah } & \multicolumn{2}{|c|}{ Tinggi } & & & \\
\hline & $\mathbf{n}$ & $\%$ & $\mathbf{n}$ & $\%$ & $\mathbf{n}$ & $\%$ & \\
\hline \multicolumn{8}{|l|}{ Umur ibu (tahun) } \\
\hline$\geq 35$ & 3 & 30,0 & 7 & 70,0 & 10 & 100 & 1,000 \\
\hline$<35$ & 28 & 31,1 & 62 & 68,9 & 90 & 100 & \\
\hline \multicolumn{8}{|l|}{ Umur ayah (tahun) } \\
\hline$\geq 35$ & 9 & 33,3 & 18 & 66,7 & 27 & 100 & 0,810 \\
\hline$<35$ & 22 & 30,1 & 51 & 69,9 & 73 & 100 & \\
\hline \multicolumn{8}{|l|}{ Besar keluarga (orang) } \\
\hline $\operatorname{Kecil~}(\leq 4)$ & 21 & 35,6 & 38 & 64,4 & 59 & 100 & 0,276 \\
\hline Besar $(>4)$ & 10 & 24,4 & 31 & 75,6 & 41 & 100 & \\
\hline \multicolumn{8}{|l|}{ Pendapatan keluarga } \\
\hline Tinggi $(\geq \operatorname{Rp} 1.450 .000)$ & 17 & 23,3 & 56 & 76,7 & 73 & 100 & 0,008 \\
\hline Rendah $(<\operatorname{Rp} 1.450 .000)$ & 14 & 51,9 & 13 & 48,1 & 27 & 100 & \\
\hline \multicolumn{8}{|l|}{ Asal suku } \\
\hline Papua & 14 & 31,8 & 30 & 68,2 & 44 & 100 & 1,000 \\
\hline Non-Papua & 17 & 30,4 & 39 & 69,6 & 56 & 100 & \\
\hline \multicolumn{8}{|l|}{ Pendidikan ibu } \\
\hline Rendah & 24 & 35,8 & 43 & 64,2 & 67 & 100 & 0,171 \\
\hline Tinggi & 7 & 21,2 & 26 & 78,8 & 33 & 100 & \\
\hline \multicolumn{8}{|l|}{ Pendidikan ayah } \\
\hline Rendah & 20 & 37,0 & 34 & 63,0 & 54 & 100 & 0,195 \\
\hline Tinggi & 11 & 23,9 & 35 & 76,1 & 46 & 100 & \\
\hline \multicolumn{8}{|l|}{ Pekerjaan ayah } \\
\hline Bekerja & 31 & 31,0 & 69 & 69,0 & 100 & 100 & - \\
\hline \multicolumn{8}{|l|}{ Pekerjaan ibu } \\
\hline Bekerja & 3 & 13,0 & 20 & 87,0 & 23 & 100 & 0,041 \\
\hline Tidak bekerja/IRT & 28 & 36,4 & 49 & 63,6 & 77 & 100 & \\
\hline \multicolumn{8}{|l|}{ Umur balita (tahun) } \\
\hline $2-3$ & 24 & 34,3 & 46 & 65,7 & 70 & 100 & 0,349 \\
\hline $4-5$ & 7 & 23,3 & 23 & 76,7 & 30 & 100 & \\
\hline \multicolumn{8}{|l|}{ Jenis kelamin } \\
\hline Perempuan & 19 & 32,2 & 40 & 67,8 & 59 & 100 & 0,465 \\
\hline Laki-laki & 12 & 29,3 & 29 & 70,7 & 41 & 100 & \\
\hline \multicolumn{8}{|l|}{ Berat badan lahir } \\
\hline Normal ( $\geq 2500 \mathrm{~g})$ & 26 & 29,9 & 61 & 70,1 & 87 & 100 & 0,534 \\
\hline $\operatorname{BBLR}(<2500 \mathrm{~g})$ & 5 & 38,5 & 8 & 61,5 & 13 & 100 & \\
\hline
\end{tabular}

Keterangan: $\mathrm{IRT}=\mathrm{ibu}$ rumah tangga; $\mathrm{BBLR}=$ berat badan lahir rendah

Berdasarkan asal suku, diketahui bahwa 44\% ibu merupakan masyarakat asli Papua dan $56 \%$ adalah pendatang. Hal ini memberi indikasi bahwa balita non asli Papua lebih rentan terkena malaria dibandingkan balita asli Papua. Masyarakat yang tinggal di daerah endemis malaria biasanya mempunyai imunitas alami sehingga mempunyai pertahanan alamiah (kebal) terhadap infeksi malaria dan imunitas berperan penting menentukan beratnya infeksi. Hal ini sejalan dengan beberapa penelitian yang menyatakan bahwa bayi di daerah endemik malaria mendapat perlindungan antibodi maternal yang diperoleh secara transplasental (10). Penelitian lain di Srilanka (11) juga menemukan bahwa penderita malaria yang tinggal di daerah endemis memiliki densitas parasit yang lebih rendah daripada yang tidak tinggal di daerah endemis. Pada penduduk 
di daerah endemis ditemukan parasitemia berat namun asimtomatik, sebaliknya pasien non-imun dari daerah non-endemis lebih mudah mengalami malaria berat. Hal ini disebabkan orang yang tinggal di daerah endemis sudah terbentuk antibodi protektifnya sehingga dapat membunuh parasit atau menetralkan toksin parasit.

\section{Karakteristik balita}

Berdasarkan umur, sebagian besar balita berumur dua sampai tiga tahun dan rata-rata umur balita adalah tiga tahun. Anak-anak usia ini adalah kelompok terbanyak yang berisiko terhadap malaria, hal ini disebabkan balita belum mampu menjaga dirinya dari gigitan nyamuk serta memiliki daya tahan tubuh yang belum maksimal. Pertahanan tubuh terhadap malaria yang diturunkan penting untuk melindungi anak dan bayi karena sifat khusus eritrosit yang relatif resisten terhadap masuk dan berkembang biaknya parasit malaria. Berdasarkan data Departemen Kesehatan tahun 2011, anak-anak usia di bawah lima tahun lebih rentan terjangkit malaria bahkan angka kematian mencapai 70\%. Jika ditinjau dari jenis kelamin, diketahui sebagian besar balita berjenis kelamin perempuan dengan persentase 59\%. Perbedaan prevalensi menurut umur dan jenis kelamin sebenarnya berkaitan dengan perbedaan derajat kekebalan karena variasi keterpaparan kepada gigitan nyamuk.

Pertumbuhan dan perkembangan anak balita juga dipengaruhi oleh berat badan lahir. Rerata berat badan lahir balita adalah $2.900 \mathrm{~g}$ dengan $13 \%$ balita memiliki berat badan lahir rendah $(<2.500 \mathrm{~g})$ dan $87 \%$ balita lainnya memiliki berat badan lahir normal. BBLR dapat meningkatkan morbiditas, menyebabkan gangguan perkembangan mental, dan meningkatkan risiko penyakit kronis. Bayi yang lahir dengan BBLR akan lebih sulit untuk memiliki ukuran tubuh normal di kemudian hari sehingga dapat menyebabkan stunting pada masa remaja (12).

\section{Pengetahuan ibu tentang malaria}

Berdasarkan pengetahuan ibu tentang malaria, diketahui bahwa 57\% ibu memiliki pengetahuan yang baik dan 43\% lainnya memiliki pengetahuan malaria yang kurang baik. Pengetahuan ibu yang kurang baik
Tabel 2. Persentase pengetahuan ibu balita tentang malaria

\begin{tabular}{lcc}
\hline \multirow{2}{*}{ Pertanyaan pengetahuan malaria } & \multicolumn{2}{c}{ Persentase (\%) } \\
\cline { 2 - 3 } & Tahu & Tidak tahu \\
\hline Jenis nyamuk penyebab malaria & 49 & 51 \\
Tempat nyamuk berkembangbiak & 53 & 47 \\
Cara penularan malaria & 39 & 61 \\
Waktu aktif nyamuk menggigit & 68 & 32 \\
Gejala awal malaria & 56 & 44 \\
Cara mencegah malaria & 46 & 54 \\
Sumber informasi malaria & 55 & 45 \\
Cara penyembuhan malaria & 83 & 17 \\
\hline
\end{tabular}

ini disebabkan rendahnya pengetahuan ibu mengenai jenis nyamuk malaria, tempat perindukan nyamuk, cara mencegah malaria yang baik, dan bagaimana gejala awal penyakit malaria (Tabel 2).

Secara teori, pengetahuan yang baik tentang penularan malaria akan dapat membantu upaya pencegahan terjadinya penularan malaria sehingga masyarakat menjadi mampu untuk bertindak, mencegah, dan mampu melindungi diri dari serangan penyakit ini. Tanda dan gejala penyakit malaria yang penting dan harus diketahui oleh orangtua adalah panas tinggi, menggigil, dan sakit kepala. Gejala penyakit malaria berupa panas dan menggigil merupakan gejala malaria yang paling banyak diketahui oleh responden sedangkan gejala lain yang juga disebutkan adalah badan yang kaku, kurus, batuk-beringus, sakit tulang belakang, bibir kering, dan muka pucat. Pengetahuan ini diketahui dari pengalaman dan penyuluhan oleh petugas kesehatan.

Hasil penelitian juga menunjukkan bahwa sebagian besar ibu belum menerapkan praktik pencegahan malaria yang baik padahal praktik pencegahan malaria sangat penting dilakukan guna menurunkan angka kesakitan malaria. Pengetahuan mengenai cara pencegahan malaria ini sangat penting, mengingat program pencegahan malaria dengan menggunakan kelambu pada masyarakat tidak begitu tepat dilakukan. Di samping itu, kondisi rumah yang tidak terpasang kasa nyamuk pada ventilasi menyebabkan nyamuk masuk ke dalam ruangan. Pada dasarnya, ibu hanya menerapkan dua sampai tiga praktik pencegahan saja dari tujuh praktik pencegahan malaria yang dianjurkan oleh dinas kesehatan setempat, padahal jika semua praktik dilakukan akan semakin efektif upaya 


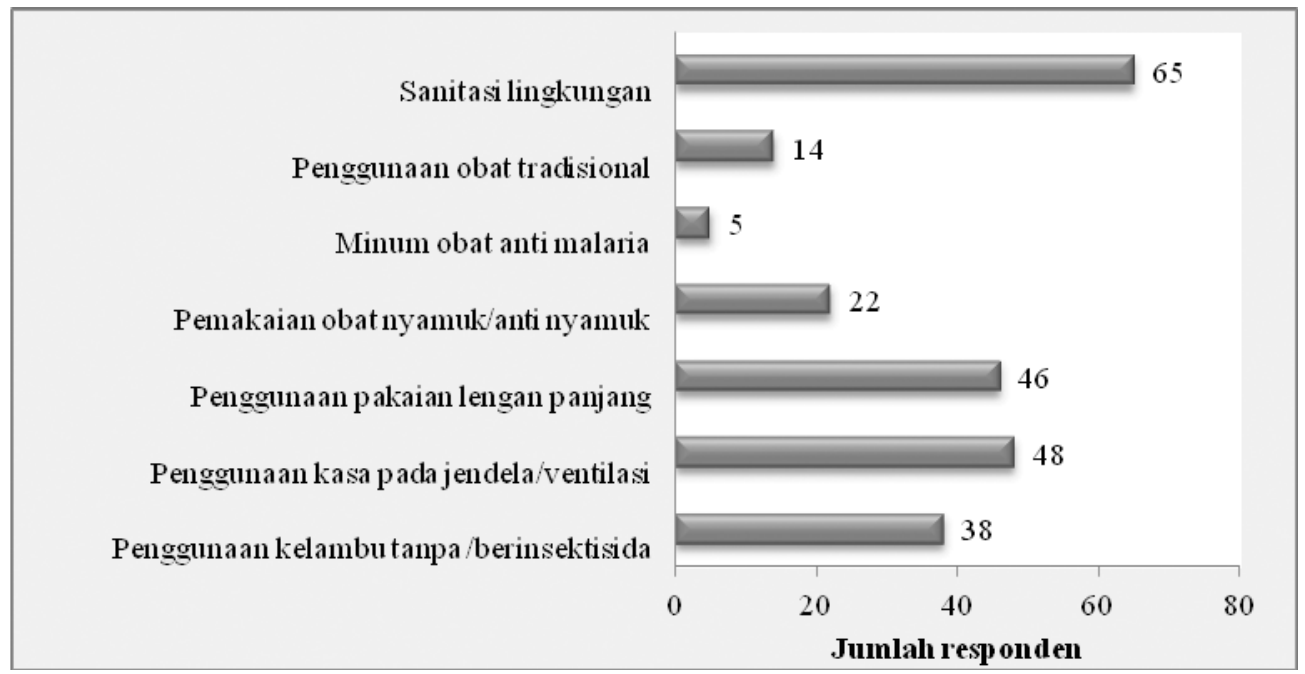

Gambar 1. Praktik ibu dalam mencegah malaria di Kabupaten Manokwari

untuk menghindarkan keluarga dari infeksi malaria. Praktik pencegahan malaria secara rinci disajikan pada Gambar 1.

Berdasarkan Gambar 1 terlihat bahwa untuk penggunaan kelambu berinsektisida dan non-insektisida cukup banyak dipraktikkan oleh ibu. Penggunaan kelambu merupakan upaya yang paling efektif mencegah digigit nyamuk pada saat tidur dibandingkan dengan upaya yang lain, hal ini disebabkan penggunaan kelambu mengurangi risiko masuknya insektisida ke dalam tubuh manusia melalui jaringan kulit serta risiko lain dari obat pengusir nyamuk yang dibakar, khususnya bagi orang yang mempunyai gangguan sistem pernapasan. Menurut keterangan, rata-rata penggunaan kelambu adalah empat tahun dan rata-rata kelambu dicuci adalah lima bulan sekali. Menurut Dinas Kesehatan Kabupaten Manokwari, penggunaan kelambu berinsektisida akan efektif selama jangka waktu 3-5 tahun dan dapat dicuci secara teratur tiga bulan sekali.

Praktik pencegahan yang paling sedikit dilakukan adalah mengonsumsi obat antimalaria, hal ini disebabkan kurangnya pengetahuan ibu tentang pentingnya mengonsumsi obat pencegahan malaria. Dulu malaria masih diobati dengan klorokuin, tetapi setelah ada laporan resistensi maka saat ini telah dikembangkan pengobatan baru dengan tidak menggunakan obat tunggal saja tetapi dengan kombinasi yaitu dengan ACT (Artemisininbased Combination Therapy) dan DHP atau Arterakin
(Dehidroartemisine piperaqui). Kedua jenis obat ini merupakan obat yang dianjurkan oleh Kementerian Kesehatan untuk dikonsumsi saat ini.

Kepercayaan atau keyakinan yang menjadi kebiasaan dalam masyarakat berpengaruh terhadap perilaku masyarakat. Berdasarkan hasil penelitian ada tradisi atau kepercayaan dalam mencegah malaria pada balita, misalnya dengan memandikan anak dengan menggunakan air rebusan daun dari pucuk pohon. Pemanfaatan tradisional tanaman obat bagi balita sakit malaria dan bagi orang dewasa umumnya adalah dengan mengonsumsi daun pepaya, daun sambiloto, serta paria untuk mengurangi gejala malaria. Daun pepaya dan paria biasanya dimanfaatkan sebagai sayuran, tetapi tidak sedikit yang memanfaatkan daun pepaya, paria serta sambiloto untuk kemudian direbus dan diambil sarinya untuk diminum.

Beberapa penelitian tentang pemanfaatan obat telah dilakukan, diantaranya penelitian tentang pemanfaatan tradisional tanaman obat-obatan dalam mengelola malaria pada penduduk Assendabo Township di Jimma, Etiopia. Diperoleh bahwa sebagian besar masyarakat Ethiopia menggunakan obat tradisional untuk mengobati malaria dan penyakit lainnya. Hasil penelitian ini kemudian menjadi dasar untuk memilih tanaman yang lebih lanjut dilakukan studi farmakologis dan fitokimia untuk mengembangkan obat baru yang relevan secara lokal sebagai agen antimalaria di Ethiopia (13). 
Hasil penelitian menyebutkan bahwa masyarakat hutan asli dan pedesaan distrik Lipis dari Pahang Malaysia (14) memiliki kesadaran akan penyakit malaria tetapi sikap dan praktik dalam pencegahan malaria tidak memadai. Selanjutnya, disebutkan bahwa warga di Kabupaten Muleba Utara Tanzania memiliki tingkat pengetahuan yang tinggi tentang malaria, tetapi pengetahuan ini belum sepenuhnya dipraktikkan dalam penggunaan intervensi malaria yang tersedia (15). Hasil penelitian tentang respon ibu terhadap anak demam di daerah perkotaan dan pedesaan di Enugu, Nigeria Tenggara menyebutkan bahwa kedua ibu di daerah perkotaan dan pedesaan menyadari bahwa malaria merupakan penyebab utama demam pada anak. Meskipun ibu di pedesaan dapat mengenali demam dan tanda-tanda bahaya dengan lebih baik daripada ibu-ibu di daerah kota, tetapi tanggapan ibu di daerah kota terhadap demam anaknya lebih baik. Ibu di daerah kota menggunakan obat klorokuin, artemisinin combination therapy (ACT), dan parasetamol sebagai obat utama untuk mengobati demam anaknya dan sudah tersedia di rumah sedangkan ibu-ibu pedesaan lebih cenderung untuk menggunakan obat sisa dari pengobatan sebelumnya untuk mengobati demam. Sementara itu, ibu di daerah perkotaan juga lebih mempraktikkan tindakan pencegahan dan mencari tindakan lebih cepat dibandingkan ibu di pedesaan dan total biaya perawatan juga lebih tinggi di daerah perkotaan (16).

\section{Kejadian malaria}

Manokwari merupakan daerah yang memiliki iklim tropis sehingga sangat mendukung kelangsungan hidup dari spesies nyamuk terutama Anopheles. Nyamuk Anopheles tersebar di Manokwari dan menyebabkan penyakit malaria tersiana dan malaria tropika dengan jumlah penderita yang cukup banyak. Dalam penelitian ini kejadian malaria terdiri dari status sakit, jenis malaria, frekuensi sakit, dan riwayat penyakit lain (Tabel 3). Pengobatan terhadap penderita malaria yang dilaksanakan di Indonesia ada dua jenis, yaitu pengobatan malaria klinis dan pengobatan radikal. Pengobatan malaria klinis merupakan pemberian obat antimalaria hanya berdasarkan gejala klinis saja sedangkan pengobatan radikal adalah pemberian obat antimalaria yang berdasarkan hasil
Tabel 3. Distribusi balita berdasarkan kejadian malaria di Puskesmas Kab. Manokwari

\begin{tabular}{lcc}
\hline \multicolumn{1}{c}{ Variabel } & \multicolumn{2}{c}{ Total } \\
\cline { 2 - 3 } & $\mathbf{n}$ & $\mathbf{\%}$ \\
\hline Kejadian malaria & & \\
$\quad$ Tinggi & 69 & 69,0 \\
$\quad$ Rendah & 31 & 31,0 \\
Status sakit malaria & & \\
$\quad$ Sakit & 82 & 82,0 \\
$\quad$ Tidak sakit & 18 & 18,0 \\
Jenis malaria & & \\
$\quad$ Berat & 42 & 42,0 \\
$\quad$ Ringan & 58 & 58,0 \\
Frekuensi sakit & & \\
$\quad \leq 2$ kali & 55 & 55,0 \\
$\quad$ 2 kali & 45 & 45,0 \\
Riwayat penyakit lain & & \\
$\quad$ Ada & 21 & 21,0 \\
$\quad$ Tidak ada & 79 & 79,0 \\
\hline
\end{tabular}

konfirmasi laboratorium. Sampai saat ini, masih banyak Provinsi yang masih melaksanakan pengobatan malaria klinis, termasuk Provinsi Papua Barat. Berdasarkan kajian dan penelitian yang dilakukan oleh Departemen Kesehatan, ternyata pengobatan dengan cara ini sering menimbulkan terjadinya kegagalan pengobatan bagi penderita malaria klinis, sebab pengobatan dengan cara ini tidak berdasarkan hasil pemeriksaan sediaan darah.

Tingginya kejadian malaria disebabkan jumlah balita yang mengalami malaria berdasarkan jenisnya, baik malaria berat dan ringan tidak berbeda jauh. Berdasarkan data diperoleh bahwa $42 \%$ balita menderita malaria berat yaitu malaria jenis tropika dan $58 \%$ balita lainnya menderita malaria ringan. Kemudian jika ditinjau dari frekuensi sakit diketahui bahwa terdapat $45 \%$ balita mengalami malaria lebih dari dua kali dalam enam bulan dan 55\% lainnya mengalami malaria kurang dari dua kali dalam enam bulan (Tabel 3).

Lama sakit infeksi yang dialami balita dapat mempengaruhi tingkat kecukupan gizi balita tersebut. Hal ini disebabkan pada saat sakit, nafsu makan anak menjadi berkurang sehingga asupan zat gizi yang berasal dari makanan pun menjadi sedikit dan secara langsung akan mempengaruhi tingkat kecukupan zat gizi anak. Riwayat penyakit lain pada balita juga menjadi penyebab tingginya kejadian malaria di Puskesmas Kabupaten Manokwari. Berdasarkan data yang diperoleh, sebanyak $21 \%$ balita 
memiliki riwayat penyakit lain seperti asma, tuberkulosis, diare, batuk, dan alergi.

Balita penderita malaria yang berobat ke unit pelayanan kesehatan, umumnya masih diobati secara pengobatan klinis, yaitu pemberian obat antimalaria hanya berdasarkan gejala klinis saja dan belum diberikan pengobatan radikal atau pemberian obat antimalaria selain gejala klinis sedangkan seharusnya menggunakan Rapid Test Diagnosis (RTD). Kondisi ini terjadi karena beberapa faktor, antara lain keterbatasan sarana dan prasarana yang dibutuhkan (mikroskop), minimnya kemampuan atau keterampilan petugas (tenaga mikroskopis malaria) terutama di daerah pedesaan, dan tidak memadainya dana operasional program penanggulangan penyakit malaria (P2 Malaria), khususnya di kabupaten atau kota dan puskesmas.

\section{Status gizi anak balita}

Status gizi anak adalah keadaan kesehatan anak yang ditentukan oleh derajat kebutuhan fisik energi dan zat-zat gizi lain yang diperoleh dari pangan dan makanan yang dampak fisiknya diukur secara antropometri (17) dan dikategorikan berdasarkan standar baku WHONCHS dengan indeks BB/U, TB/U, dan BB/TB. Ratarata status gizi balita berdasarkan $\mathrm{BB} / \mathrm{TB}, \mathrm{TB} / \mathrm{U}$, dan BB/U tergolong normal (69\%, 79\%, dan 55\%) (Tabel 4). Anak balita dengan status gizi buruk dan gizi lebih tidak ditemukan dalam penelitian ini. Dari ketiga indeks yang digunakan dalam penelitian ini dapat diambil kesimpulan bahwa status gizi anak balita di masa lampau pada umumnya berada pada kategori normal dan pada saat penelitian berada dalam keadaan tidak normal. Hal ini disebabkan pada saat penelitian, balita mengalami sakit sehingga berpengaruh terhadap nafsu makan yang secara langsung berpengaruh terhadap berat badan balita.

Berdasarkan hasil analisis Chi-Square diketahui bahwa variabel yang berhubungan dengan kejadian malaria adalah status gizi sedangkan variabel yang berhubungan dengan status gizi adalah pendidikan ibu $(\mathrm{p}=0,005)$, pendidikan ayah $(\mathrm{p}=0,027)$, pekerjaan ibu $(\mathrm{p}=0,055)$, pendapatan keluarga $(\mathrm{p}=0,000)$, dan pengetahuan ibu tentang malaria $(\mathrm{p}=0,000)$. Selanjutnya (Tabel 5) adalah hasil analisis regresi logistik untuk mengetahui variabel yang paling berpengaruh terhadap status gizi balita.
Tabel 4. Distribusi balita berdasarkan status gizi di Puskesmas Kabupaten Manokwari

\begin{tabular}{lcc}
\hline \multirow{2}{*}{ Status gizi } & \multicolumn{2}{c}{ Total } \\
\cline { 2 - 3 } & $\mathbf{n}$ & $\mathbf{\%}$ \\
\hline BB/TB & 69 & 69,0 \\
$\quad$ Normal & 31 & 31,0 \\
$\quad$ Tidak normal & & \\
TB/U & 79 & 79,0 \\
$\quad$ Normal & 21 & 21,0 \\
$\quad$ Tidak normal & & \\
BB/U & 55 & 55,0 \\
$\quad$ Normal & 45 & 45,0 \\
$\quad$ Tidak normal & &
\end{tabular}

Tabel 5. Hasil uji regresi logistik faktor-faktor yang berpengaruh terhadap status gizi balita

\begin{tabular}{lcccc}
\hline Variabel & Sig. & OR & \multicolumn{2}{c}{$\mathbf{9 5 \% C I}$} \\
\hline Pendidikan ibu & 0,065 & 4,662 & 0,908 & 5,939 \\
Pendidikan ayah & 0,508 & 1,603 & 0,397 & 6,470 \\
Pekerjaan ibu & 0,124 & 4,286 & 0,672 & 7,355 \\
Pendapatan keluarga & 0,091 & 0,263 & 0,056 & 1,239 \\
$\begin{array}{l}\text { Pengetahuan tentang } \\
\text { malaria }\end{array}$ & $0,002^{*}$ & 0,115 & 0,029 & 0,456 \\
Kejadian malaria & $0,007^{*}$ & 0,039 & 0,004 & 0,405 \\
Constant & 0,022 & 15,961 & & \\
\hline
\end{tabular}

*Signifikan $\mathrm{p}<0.05$

\section{BAHASAN}

Berdasarkan karakteristik sosial ekonomi keluarga, tingginya kejadian malaria lebih banyak dialami oleh balita yang memiliki orangtua berumur kurang dari 35 tahun, memiliki jumlah anggota keluarga kecil, pendidikan orangtua rendah, dan ibu tidak bekerja. Kejadian malaria yang tinggi lebih banyak dialami oleh balita berumur dua sampai tiga tahun, berjenis kelamin perempuan, dan memiliki berat badan lahir yang normal.

Hasil uji Chi-Square menunjukkan bahwa terdapat hubungan antara pendapatan keluarga dengan kejadian malaria ( $\mathrm{p}=0,008)$. Banyaknya anggota keluarga sangat mempengaruhi konsumsi pangan dalam keluarga, sebagaimana yang dinyatakan bahwa terdapat hubungan yang bermakna antara besar keluarga dan kejadian kurang gizi pada masing-masing keluarga (18). Jumlah anggota keluarga yang semakin besar tanpa diimbangi dengan meningkatnya pendapatan akan menyebabkan pendistribusian konsumsi pangan semakin tidak 
merata. Pendapatan merupakan salah satu faktor yang menentukan kuantitas dan kualitas makanan yang dikonsumsi sehingga berhubungan erat dengan status gizi (19). Keadaan ekonomi keluarga yang kurang mampu merupakan faktor yang kurang mendukung bagi pertumbuhan dan perkembangan balita. Hal ini disebabkan tingkat pendapatan keluarga sangat berpengaruh terhadap konsumsi pangan keluarga. Hasil penelitian menunjukkan bahwa sebagian kecil ibu memiliki pendapatan keluarga di bawah UMR Provinsi Papua Barat yakni kurang dari Rp 1.450.000.

Sebagian besar pendapatan keluarga yang tinggi berasal dari masyarakat pendatang, balita asal pendatang atau non-asli Papua lebih rentan terhadap malaria dibandingkan balita dari suku asli Papua. Selanjutnya, hasil uji Chi-Square juga menunjukkan bahwa ada hubungan antara pekerjaan ibu dengan kejadian malaria $(p=0,041)$. Ibu yang tidak bekerja umumnya berpendidikan rendah dan memiliki pengetahuan yang kurang mengenai praktik dan pencegahan malaria dibandingkan ibu yang bekerja sehingga kejadian malaria lebih banyak dialami oleh anak-anak yang berasal dari ibu yang tidak memiliki pekerjaan. Namun, ada juga ibu bekerja yang membawa anaknya ketika bekerja tanpa melindungi mereka dari gigitan nyamuk. Sebagian besar ibu belum menerapkan praktik pencegahan malaria yang baik. Praktik pencegahan malaria sangat penting dilakukan guna menurunkan angka kesakitan malaria. Pengetahuan mengenai cara pencegahan malaria ini sangat penting mengingat program pencegahan malaria dengan menggunakan kelambu pada masyarakat tidak begitu tepat dilakukan.

Di samping itu, kondisi rumah yang tidak terpasang kasa nyamuk pada ventilasi menyebabkan nyamuk masuk ke dalam ruangan. Penelitian di daerah pedesaan seperti Warmare dan Prafi, ditemukan banyak rumah yang tidak menggunakan kasa pada jendela dan ventilasi dibandingkan di daerah perkotaan seperti Sanggeng dan Wosi sehingga kebiasaan menggunakan kelambu lebih banyak ditemukan di pedesaan dibandingkan di perkotaan. Sementara itu, kebiasaan menggunakan obat antinyamuk semprot dan elektrik lebih banyak dilakukan oleh ibu yang berada di perkotaan. Pada dasarnya, ibu hanya menerapkan dua sampai tiga praktik pencegahan saja dari tujuh praktik pencegahan malaria yang dianjurkan oleh dinas kesehatan setempat, padahal jika semua praktik dilakukan akan semakin efektif upaya untuk menghindarkan keluarga dari infeksi malaria.

Hasil uji Chi-Square menunjukkan bahwa ada hubungan antara kejadian malaria dengan status gizi balita $(p<0,05)$. Sebagian besar balita yang datang ke puskesmas menderita malaria dengan tipe malaria yang berbeda. Beberapa studi menunjukkan bahwa anak yang bergizi baik justru lebih sering mendapat kejang dan malaria dibandingkan dengan anak yang bergizi buruk. Namun, anak yang bergizi baik dapat mengatasi malaria berat dengan lebih cepat dibandingkan anak yang bergizi buruk (20). Selain itu, diketahui bahwa tidak ada hubungan antara tingkat kecukupan energi, protein, vitamin $\mathrm{A}$, vitamin $\mathrm{C}$, dan vitamin $\mathrm{B} 12$ dengan status malaria $(p>0,05)$. Berbeda dengan peneliti lain (21) yang menyatakan bahwa prevalensi malaria lebih tinggi pada anak-anak yang belum menerima suplemen vitamin A dibandingkan dengan anak yang telah mendapatkan suplemen vitamin A. Penelitian sebelumnya (3) menyebutkan bahwa infeksi malaria mempengaruhi penurunan status gizi anak balita di Purworejo, sebaliknya penelitian lain menyebutkan bahwa kejadian malaria tidak berhubungan dengan status gizi pada balita di Kecamatan Kokap dan Samigaluh Kabupaten Kulon Progo Provinsi DIY (4). Berdasarkan hasil penelitian disebutkan juga bahwa malaria dan kekurangan gizi menjadi penyebab morbiditas dan mortalitas yang tinggi di daerah pedesaan sub-Sahara Afrika. Ditemukan bahwa anak-anak kekurangan gizi kronis memiliki risiko lebih tinggi untuk mengalami malaria (5).

Selanjutnya, berdasarkan analisis regresi logistik diperoleh nilai OR kejadian malaria sebesar 0,039 (95\% CI: 0,004-0,405). Artinya, kejadian malaria merupakan faktor pendorong status gizi balita yang kurang baik. Hal ini berarti bahwa balita dengan kejadian malaria yang rendah berpeluang 0,113 lebih kecil memiliki status gizi kurang dibandingkan balita dengan kejadian malaria tinggi. Hasil ini didukung oleh penelitian yang menunjukkan bahwa balita dengan status gizi kurang berisiko menderita malaria 1,86 kali dibandingkan dengan yang berstatus gizi baik (22). Lebih lanjut, penelitian yang menguji hubungan antara malaria dan status gizi 
menunjukkan bahwa malnutrisi protein dan energi mempunyai hubungan dengan morbiditas dan mortalitas pada berbagai malaria (23). Berbeda dengan penelitian lain yang menyatakan bahwa tidak ada hubungan antara KEP dan morbiditas malaria, tetapi anak kekurangan gizi memiliki risiko lebih dari dua kali lipat lebih tinggi meninggal dibandingkan anak tanpa kekurangan gizi (24).

Berdasarkan uji regresi linier diperoleh nilai OR pengetahuan ibu tentang malaria sebesar 0,115 (95\% CI: 0,029-0,456) sehingga pengetahuan ibu tentang malaria merupakan faktor pencegah status gizi balita yang kurang baik. Hal ini berarti bahwa ibu dengan pengetahuan malaria yang baik berpeluang lebih kecil memiliki anak dengan status gizi kurang dibandingkan ibu yang memiliki pengetahuan malaria yang kurang baik. Penelitian serupa menyebutkan bahwa warga di Kabupaten Muleba Utara Tanzania memiliki tingkat pengetahuan yang tinggi tentang malaria, tetapi pengetahuan ini belum sepenuhnya dipraktikkan dalam penggunaan intervensi malaria yang tersedia (15). Penelitian lain menyebutkan bahwa masyarakat hutan asli dan pedesaan Distrik Lipis dari Pahang Malaysia memiliki kesadaran akan penyakit malaria tetapi sikap dan praktik dalam pencegahan malaria tidak memadai (14).

\section{SIMPULAN DAN SARAN}

Berdasarkan hasil penelitian maka dapat disimpulkan bahwa tingkat kejadian malaria pada balita di Kabupaten Manokwari tergolong tinggi, status gizi balita pada masa lampau berada pada kategori normal dan status gizi pada saat penelitian berada dalam keadaan tidak normal. Hal ini disebabkan pada saat penelitian banyak balita mengalami sakit sehingga berpengaruh terhadap nafsu makan yang secara langsung berpengaruh terhadap berat badan balita. Selanjutnya, diketahui bahwa terdapat hubungan antara kejadian malaria dengan status gizi balita di Kabupaten Manokwari.

Disarankan kepada masyarakat, khususnya para ibu untuk menerapkan tujuh praktik pencegahan malaria yang disarankan oleh Dinas Kesehatan, perlu memperhatikan kebersihan penggunaan kelambu mengingat rata-rata kelambu dicuci hanya 5 bulan sekali. Di samping itu, disarankan untuk mengonsumsi obat antimalaria, menjaga kebersihan lingkungan serta memiliki kepatuhan dalam konsumsi obat. Dinas Kesehatan pun perlu meningkatkan promosi kepada masyarakat tentang pentingnya praktik pencegahan malaria mengingat hanya 2-3 praktik saja yang dilakukan.

\section{RUJUKAN}

1. Gomez A, Dominguez E. Malaria treatment in severe malnutrition in Angola. [series online] 2004 [cited 2012 Maret 21]. Available from: URL: http.//www.ennonline. net/fex/21/malaria

2. Departemen Kesehatan. Riset Kesehatan Dasar(Riskesdas). Laporan hasil riset kesehatan dasar Indonesia. Jakarta: Departemen Kesehatan Republik Indonesia; 2010.

3. Nurhadimuda. Hubungan infeksi malaria dengan status gizi balita di daerah endemis malaria Kabupaten Purworejo [Tesis]. Yogyakarta: Universitas Gajah Mada; 2003.

4. Tarmidzi M. Hubungan antara kejadian malaria dengan status gizi balita di Kecamatan Kokap dan Samigaluh Kabupaten Kulon Progo Provinsi D.I. Yogyakarta [Tesis]. Yogyakarta: Universitas Gajah Mada; 2006.

5. Deen JL, Walraven GEL, Seidlein LV. Increased risk for malaria in chronically malnourished children under 5 years of age in Rural Gambia. J Trop Pediatr 2002;48(2):78-83.

6. Jeremiah ZA, Uko EK. Childhood asymptomatic malaria and nutritional status among Port Harcourt children. East Afr J Public Health 2007;4(2):55-8.

7. Dinas Kesehatan Kabupaten Manokwari. Laporan Kesehatan Kabupaten Manokwari. Papua: Dinas Kesehatan Kabupaten Manokwari; 2010.

8. Notoatmodjo. Metodologi penelitian kesehatan. Jakarta: PT. Rineka Cipta; 2003.

9. Gumala Y. Perbedaan tingkat konsumsi energi, protein, dan status gizi balita menurut peran ibu di Kabupaten Gianyar [Tesis]. Yogyakarta: Universitas Gadjah Mada; 2002.

10. Anies. Waspada ancaman penyakit tidak menular. Jakarta: PT. Elex. Media Komputindo; 2006.

11. Karunaweera, Carter R, Grau GE, Mendis KN. Demonstration of anti-disease immunity to Plasmodium vivax malaria in Sri Lanka using a quantitative method to assess clinical disease. Am J Trop Med Hyg 1998;58(2):204-10.

12. Muthayya S. Maternal nutrition \& low birth weight: what is really important?. Indian $\mathrm{J}$ of Med Resc 2009;130(5);600-8.

13. Suleman S, Mekonnen Z, Tilahun G, Chatterjee S. Utilization of traditional antimalarial ethnophytotherapeutic remedies among assendabo inhabitants in (South-West) Ethiopia. Current Drug Therapy 2009;4(2):78-91. 
14. Adhroey AL, Nor ZM, Mekhlafi AL, Mahmud R. Opportunities and obstacles to the elimination of malaria from Peninsular Malaysia: knowledge, attitudes and practices on malaria among aboriginal and rural communities. Malar J 2010;9:137.

15. Kinung'hi SM, Mashauri F, Mwanga JR, Nnko SE, Kaatano GM, Malima R, Kishamawe C, Magesa S, Mboera LE. Knowledge, attitudes and practices about malaria among communities: comparing epidemic and non-epidemic prone communities of Muleba District, North-Western Tanzania. BMC Public Health 2010;10:395.

16. Uzochukwu BSC, Onwujekwe EO, Onoka CA, Ughasoro MD. Rural-urban differences in maternal responses to childhood fever in South East Nigeria. PLoS ONE 2008;3(3):e1788.

17. Suhardjo. Gizi dan pangan. Yogyakarta: Kanisius; 1996.

18. Suhardjo. Sosio budaya gizi. Bogor: IPB PAU; 1989.

19. Suhardjo. Berbagai cara pendidikan gizi. Bogor: Bumi Aksara; 2003.
20. Harijanto PN. Gejala klinik malaria. Dalam: Harijanto PN (editor). Malaria, epidemiologi, patogenesis, manifestasi klinis dan penanganan. Jakarta: EGC; 2000.

21. Nankabirwa V, Tylleskar T, Nankunda J, Engebretsen IM, Sommerfelt H, Tumwine JK; PROMISE EBF Research Consortium. Malaria parasitaemia among infants and its association with breastfeeding peer counselling and vitamin A supplementation: a secondary analysis of a cluster randomized trial. PLoS ONE 2011;6(7):e21862.

22. Suwadera M. Beberapa faktor risiko lingkungan rumah tangga yang berhubungan dengan kejadian malaria [Tesis]. Jakarta: Universitas Indonesia; 2003.

23. Wanti, Silviyanti E. Penyakit malaria dan KEP pada anak balita di Kabupaten Sikka Provinsi NTT. [Tesis]. Yogyakarta: Universitas Gajah Mada; 2008.

24. Olaf M, Michel G, Bocar K, Heiko B. The association between protein-energy malnutrition, malaria morbidity and all-cause mortality in West African Children. Trop Med Int Health 2003;8(6):507-11. 